\title{
The Effect of Low-Intensity Hairmyres Exercises on Six-Minute Walk Distance in Patients with Chronic Obstructive Pulmonary Disease: A Preliminary Study
}

\section{Nury Nusdwinuringtyas ${ }^{1}$, Johan Talesu ${ }^{1}$, Anita Ratnawati ${ }^{2}$, Sabarinah B. Prasetyo ${ }^{3}$}

${ }^{1}$ Department of Physical Medicine and Rehabilitation,Universitas Indonesia, Dr. Cipto Mangunkusumo Hospital, Jakarta

2 Department of Physical Medicine and Rehabilitation, Persahabatan National Respiratory Hospital, Jakarta, Indonesia

${ }^{3}$ Faculty of Public Health, Universitas Indonesia, Jakarta

\begin{abstract}
Introduction: Therapeutic exercise is the main rehabilitation program in patients with Chronic Obstructive Pulmonary Disease (COPD). Shortness of breath due to persistent obstruction causes disability in the form of decreased functional capacity. Hairmyers is an isolated group of exercise to recondition the limb muscles without weights. The purpose of this study was to assess the efficacy of low-intensity Hairmyres exercise in improving Six-Minute Walk Distance (6MWD).

Methods: This is a pre-post interventional study held from January to April 2005. Hairmyres exercises were given to the patients $(\mathrm{n}=14)$ with moderate and severe COPD for eight weeks, five times a week with two exercises performed in front of the researcher. Six-Minute Walk Distance was measured before, at the end of the $4^{\text {th }}$ week, and after the exercise program.

Results: Compared to the beginning, the 6MWD increased by 27 meters at the end of the $4^{\text {th }}$ week and 62.29 meters at the end of the program in moderate COPD patients, while the increase in severe COPD patients were 39.71 and 76 meters, respectively. There was a significant difference $(p<0.05)$ between the first and the last measurement in both groups. This difference also surpassed the minimal clinically important difference (MCID) of 6MWD.
\end{abstract}

Keywords: COPD, Hairmyers, Low-Intensity Exercise, 6MWD 


\section{ABSTRAK}

Pendahuluan: Latihan Terapeutik merupakan kunci utama program rehabilitasi pada penderita Penyakit Paru Obstruktif Kronik (PPOK). Sesak karena obstruksi yang persiten berakibat terjadi disabilitas berupa menurunnya kapasitas fungsional. Hairmyers merupakan latihan otot kelompok terisolasi tanpa beban, untuk merekondisi otot ekstremitas. Tujuan dari studi ini untuk menilai efikasi latihan intensitas rendah Hairmyres terhadap jarak tempuh Uji Jalan Enam Menit atau Six Minutes Walking Distance (6MWD)

Metode: Antara Januari 2005 hingga April 2005 dilakukan studi intervensi eksperimental pra dan pasca perlakuan. Diberikan latihan senam Hairmyres selama delapan minggu pada 14 pasien PPOK sedang dan berat. Latihan diberikan lima kali per minggu dengan dua latihan di depan peneliti. Data 6MWD diambil sebelum pemberian latihan, pada akhir minggu keempat, dan akhir latihan.

Hasil: Perubahan jarak tempuh antara awal penelitian dengan akhir minggu ke-4 dan kemudian dengan jarak tempuh akhir intervensi, pada PPOK derajat sedang masing-masing adalah 27 meter dan 62,29 meter sedangkan untuk PPOK derajat berat masing-masing 39,71 meter dan 76 meter. Terdapat perbedaan yang sangat bermakna $(p<0,05)$ antara jarak tempuh pertama dan yang terakhir serta mencapai perbedaan penting klinis minimal.

Kata Kunci: Hairmyers, Latihan intensitas rendah, PPOK.

\section{Correspondent Detail:}

\section{Nury Nusdwinuringtyas}

Email : nury_nus@yahoo.com

Department of Physical Medicine and

Rehabilitation, Universitas Indonesia,

Dr. Cipto Mangunkusumo Hospital, Jakarta

\section{INTRODUCTION}

Therapeutic exercise is a planned and systematic process to achieve therapeutic goals. ${ }^{1,2}$ Therapeutic exercise is a key component of pulmonary rehabilitation programs in Chronic Obstructive Pulmonary Disease (COPD). ${ }^{3}$ COPD is primarily a lung disease that characterized by airway obstruction and inflammation. In addition, COPD accompanied by several extra-pulmonary consequences, such as skeletal muscle weakness. ${ }^{4}$
It is one of the major cause of chronic morbidity and mortality in the world. ${ }^{5}$

Muscle dysfunction is caused by the increased rate of protein degradation and the decreased rate of protein synthesis in chronic disease. The etiologic factors are chronic hypoxia, pulmonary hyperinflation for the respiratory muscles, systemic inflammation and deconditioning secondary to lower physical activity. ${ }^{6}$

Deconditioning is the result of the reduction in physical activity that, as previously mentioned, is frequent in COPD patients as a consequence of their ventilatory limitation, a sedentary lifestyle, and reactive depression. The effects of deconditioning are especially evident in limb muscles. There is a strong evidence for the key role of deconditioning in limb muscle changes since many of the structural and biochemical changes observed in COPD are similar to those 
induced by disuse (fibers become smaller and the proportion of type II fibers increases). ${ }^{6}$

Hairmyers are therapeutic exercises with low intensity to recondition the peripheral muscles with the aim of increasing exercise tolerance. ${ }^{7,8}$ The risk of musculoskeletal injury, as well as breathlessness will be minimized by exercising each muscle group in isolated and unloaded condition., ${ }^{7,9}$ The program given improves individual muscle strength, whole body endurance, and mobility function. This exercise contains upper and lower limb movements and also work of the abdominal muscles in sitting position. ${ }^{7,8}$

\section{Table 1. Circuit of Conditioning Exercises Designed to Improve Patient's Strength and Mobility}

1. Shoulder shrugging; circle shoulder girdle forward, downward, backward and upward. Keep timing constant allowing two full seconds per circle. Relaxation encouraged throughout. Continue for 30 seconds. Repeat the exercise three times with short rest intervals between sets until Borg score is less than 3 .

2. Full arm circling; one arm at a time, passing arm as near as possible to the side of the head, circle arm is as possible. (Allow 8-10 seconds per complete circle). Repeat the exercise three times with short rest intervals between. Repeat with the other arm.

3. Increasing arm circles; hold arm away from body at shoulder height. Progressively increase size of circle for a count of six circles in 10 seconds the decrease for further count of six. Repeat after 40 seconds. Repeat with the other arm.

4. Abdominal exercise: sit on a chair, tighten abdominal muscles, hold for count of four and then release muscles over four seconds to starting position. Repeat continuously for 30 seconds. Perform the procedure three times with short rest periods in between.

5. Wall press-ups: stand with feet a full arm length distance from wall, place hand on wall and bend at elbow until nose touches the wall, push arm straight again allowing eight seconds approximately from start to completion. Repeat for 40 seconds continuously to a total of five repetitions. Repeat procedure three times with short rest periods in between.

6. Sitting to standing: using dining room chair, sit, stand, sit allowing 8-10 seconds from start to completion. Repeat continuously for 40 seconds to a total of five repetitions. Perform exercise three times with short rest intervals in between.

7. Quadriceps exercise: sit on a chair, straighten right knee, tighten thigh muscle, hold for 4 seconds. The relax gradually over a further four seconds to a total of five repetitions over 40 seconds. Repeat the exercise three times with short rest periods in between. Repeat procedure with left leg.

8. Calf exercise: hold onto the back of a chair, go up on toes and back to the floor taking 8-10 seconds to complete the procedure. Repeat continuously for 40 seconds.

9. Calf alternates/ walking on the spot: hold onto the back of a chair, allow one knee to bend, keeping toes on the ground. Bend other knee, while straightening the previous knee and allow 4 seconds for complete procedure. Repeat this bending/straightening of knees, i.e walking on the spot, keeping toes on the ground continuously for 40 seconds to a total of 10 repetitions. Repeat the exercise three times with short rest periods in between.

10. Step-ups: step up with right foot onto the step then bring up left foot. Step down with right foot followed by left foot. Allow four seconds for the complete procedure and repeat continuously for 40 seconds. Repeat the exercise three times with short rest periods in between. 
In this study, the effect of Hairmyres exercise on functional capacity was measured by 6-minute walk distance (6MWD). This walking tests are simple and widely used to assess the functional status of patient with cardiopulmonary disorder. The most widely used parameter for functional capacity in patients with COPD is the 6MWD. Its reproducibility and responsivity as an assessment tools in patients with COPD has already been tested in many researches. ${ }^{10,11}$ Functional status here is assessed by obtaining walking distance. The results of this study are expected to provide benefits for the management of pulmonary rehabilitation in patients with COPD.

\section{METHOD}

This study is a pre-post interventional study with COPD outpatients at RSUPN Dr. Cipto Mangunkusumo and RSU Persahabatan Jakarta. Inclusion criteria were as follows: (1) COPDdiagnosed with moderate and severe criteria according to the classification of the Global initiative for chronic Obstructive Lung Disease (GOLD), (2) male or female aged 40-65 years old, (3) no history of asthma, (4) not experiencing exacerbations and had received optimal medical treatment, (5) not attending gymnastics or other types of training, (6) willing to join the program voluntarily, and (7) understood Indonesian language.

Exclusion criteria include: (1) history of cardiovascular, neuromuscular or musculoskeletal diseases that limit or interfere with movement, (2) history of cognitive impairment, and (3) was not able to do at least two out of ten Hairmyres gymnastic movements. Subjects will fail if they: (1) did not perform the exercises at home three times in a row, (2) did not come to the training ground three times in a row, or (3) did not perform a total of at least 12 exercises. This study has passed the ethical review by the Ethics Committee of the Faculty of Medicine, University of Indonesia (No: 149/PT02.FK/ETIK/2004) and was conducted from January to April 2005.

Subjects were required to perform the Hairmyers exercises for eight weeks, five times a week with two exercises performed in front of the researcher. Subjects were also given a diary containing the amount and time of exercise which had to be filled every day and signed by witnesses/motivators. The 6MWD was measured before, at end of the 4th week, and after the exercise program. The data was then analyzed with paired t-test and the result would be considered significant if $p$-value $<0.05$ was obtained. The obtained difference would also be compared to the MCID of 6MWD.

Table 2. Characteristicts of subject based on COPD Degrees

\begin{tabular}{|c|c|c|c|}
\hline \multicolumn{4}{|c|}{ COPD } \\
\hline & $\begin{array}{c}\text { Moderate }(n=7) \\
\text { Mean } \pm \text { SD }\end{array}$ & $\begin{array}{c}\text { Severe }(n=7) \\
\text { Mean } \pm \text { SD }\end{array}$ & $p$ \\
\hline Gender: male & 4 & 7 & \\
\hline female & 3 & & \\
\hline Age (y.o) & $62 \pm 5.09$ & $66 \pm 3.21$ & 0.143 \\
\hline Body weight $(\mathrm{kg})$ & $56.4 \pm 13.50$ & $58.1 \pm 11.33$ & 0.801 \\
\hline Body height $(\mathrm{cm})$ & $158.7 \pm 6.52$ & $168.7 \pm 7.11$ & 0.018 \\
\hline BMI & $21.9 \pm 4.24$ & $20.4 \pm 3.42$ & 0.458 \\
\hline
\end{tabular}

$\mathrm{n}=$ Subject, $\mathrm{p}=$ Independent Sample T-test, $\mathrm{SD}=$ Standard Deviation, COPD $=$ Chronic Obstrictive Pulmonary Disease 


\section{RESULTS}

There were 17 patients who met the inclusion criteria. Three subjects were excluded so the total number of subjects who participated in this study from the beginning to the end was 14 patients. Table 2 shows the characteristics of the subjects based on the degree of COPD. Half of the subjects had moderate COPD $(n=7)$; the rest had severe COPD ( $n=7)$. Table 2 shows baseline data, including 6MWD of the subjects. Results were analyzed and discussed between the two groups, moderate and severe COPD. The data was analyzed using independent t-test to compare the measured results between the two groups.

In the moderate COPD group, three subjects were female whereas all subjects were male in the severe group. Age, body weight and BMI between the two groups did not differ significantly ( $\mathrm{p}>0.05)$. In the moderate COPD group, age ranged between $62 \pm 5.09$ years, body weight $56.4 \pm 13.50 \mathrm{~kg}$, and BMI $21.9 \pm 4.24 \mathrm{~kg} / \mathrm{m}^{2}$. In the severe COPD group, age ranged between $66 \pm 3.21$ years, body weight $58.1 \pm 11.33 \mathrm{~kg}$, and BMI $20.4 \pm 3.42 \mathrm{~kg} /$ $\mathrm{m} 2$. Although there was no significant difference of BMI between the two groups, the body height was significantly different $(158.7 \pm 6.52 \mathrm{~cm}$ in moderate COPD group and $168.7 \pm 7.11 \mathrm{~cm}$ in severe COPD group).

Table 3 shows that the $6 \mathrm{MWD}$, both in moderate and severe COPD group, increased in the second and third measurement compared to the first. The 6MWD of the moderate COPD group at the beginning of the study was $340.57 \pm 38.94$ meters, while the severe COPD group was 261.86 \pm 74.86 meters. At the end of the 4th week, the 6MWD of both groups were $367.57 \pm 34.32$ meters and $301.57 \pm 81.18$ meters, respectively. After 8 weeks of exercise program, the 6MWD of both groups were $402.86 \pm 38.37$ meters and $337.86 \pm 91.62$ meters, respectively. At the first measurement, the two groups had statistically significant difference $(\mathrm{p}<0.05)$, but at the second and third measurement, no difference was found between the two groups ( $p>0.05)$.

Table 3. The result of six minute walk test at moderate and severe COPD

\begin{tabular}{cccc}
\hline & \multicolumn{2}{c}{ COPD } & \\
& $\begin{array}{c}\text { Moderate (n=7) } \\
\text { Mean } \pm \text { SD }\end{array}$ & $\begin{array}{c}\text { Severe (n=7) } \\
\text { Mean } \pm \text { SD }\end{array}$ & $p$ \\
\hline 6MWD-I (meter) & $340.57 \pm 38.94$ & $261.86 \pm 74.86$ & 0.029 \\
6MWD-II (meter) & $367.57 \pm 34.32$ & $301.57 \pm 81.18$ & 0.071 \\
6MWD-III (meter) & $402.86 \pm 38.37$ & $337.86 \pm 91.62$ & 0.109 \\
\hline
\end{tabular}

$\mathrm{n}=$ Subject, $\mathrm{p}=$ Independent Sample T-test, $\mathrm{SD}=$ Standard Deviation, COPD $=$ Chronic Obstrictive Pulmonary Disease 
Table 4. Comparison of 6MWD distance on Moderate and Severe COPD

\begin{tabular}{ccccc}
\hline & \multicolumn{2}{c}{ Moderate COPD } & \multicolumn{2}{c}{ Severe COPD } \\
& Difference (m) & $\mathbf{p}$ & Difference (m) & p \\
\hline 6MWD-I and 6MWD-II & 27 & 0,019 & 39,71 & 0,140 \\
6MWD-II and 6MWD III & 35,29 & 0,001 & 36,29 & 0,033 \\
6MWD-I and 6MWD-III & 62,29 & 0,000 & 76 & 0,026 \\
\hline
\end{tabular}

$\mathrm{p}=$ paired t-test,$(\mathrm{m})=$ meter, $\mathrm{COPD}=$ Chronic Obstrictive Pulmonary Disease

In Table 4, we can see the difference of 6MWD between the measurements. The data were analyzed within each of the COPD group and presented as a difference in distance between the first and the second measurement, the first and the third measurement, as well as the second and the third measurement. From the data it was found that the severe COPD group had higher 6MWD improvement compared to the moderate group. The improvements were statistically significant for all comparisons $(\mathrm{p}<0.05)$, both in moderate and severe COPD group, except for the difference between the first and the second measurement in severe COPD group $(\mathrm{p}>0.05)$.

\section{DISCUSSION}

This study was conducted in 2005 , but the data was reproduced with the main focus of 6MWD as the result of the intervention. Although highintensity exercise is now a trend in pulmonary rehabilitation, ${ }^{12}$ low-intensity exercise was still given in some conditions. ${ }^{13,14}$ Regardless of the intensity target, exercise always starts with low intensity. The aim is to prevent muscle tightness, in addition to musculoskeletal injuries. ${ }^{7,8}$
Therapeutic exercise includes aerobic and/or resistance exercise training. ${ }^{15}$ COPD does not only affect the lungs, but also systemically results in the deconditioning of skeletal muscles. ${ }^{6}$ The cause of peripheral muscle dysfunction has not been completely elucidated, but it is generally accepted that at least for the limbs, muscle deconditioning results from a reduction in physical activity. ${ }^{6}$ Hairmyers are therapeutic exercises programmed to recondition skeletal muscles to avoid injury when the body is given aerobic and/or weight training.

The effect of Hairmyres exercise on functional capacity was examined using 6-minute walk test (6MWT). This walking tests are simple and widely used to assess the functional status of patient with cardiopulmonary disorder. The most widely used parameter for functional capacity in patients with COPD is the 6MWD. Its reproducibility and responsivity as an assessment tools in patients with COPD has already been tested in many researches. ${ }^{10,11}$ Six minute walk test has some advantages. The main advantages are its simplicity, minimal technological requirements, and also the vital signs and symptoms can be measured during the test. The 6MWD reflects the limitations in the activities of daily living and has 
been demonstrated to be more accurate and more sensitive than treadmill test because it objectively measures oxygen desaturation during exercise in patients with COPD. ${ }^{10}$ The walking distance has been known has a correlation with pulmonary function, health-related quality of life, maximum exercise capacity, and mortality. ${ }^{16}$

Hairmyers consists of 10 stages, starting with the first stage, the second stage and so on, and are continued according to the tolerance ability of the practice. Each movement lasts for 30 seconds and a 5-minute rest is allowed between two movements. The duration of the movement is increased to 40-60 seconds when the Borg scale is low. Although it is a type low-intensity training without using any weights, in the evaluation there is a significant increase in 6MWD. ${ }^{8}$

Patient with moderate and severe COPD cannot be able to participate in whole body endurance training. They have a higher risk to have a musculoskeletal injury and breathlessness that can be minimized by exercising each muscle group in isolation and unloaded. This kind of exercise has already proven can improves individual muscle strength, endurance, and mobility. This exercise consist of upper and lower limb movements and work of the abdominal muscles in sitting position (Table 1). ${ }^{7}$

In 2005 the research was conducted on moderate and severe COPD patients. According to GOLD 2002, moderate COPD is divided into II A, FEV1 between 30 to $80 \%$ of prediction and II B FEV 1 between $30-50 \%$ of prediction; while severe COPD is under $30 \%$ or below $50 \%$. According to GOLD 2020 , moderate COPD is between $50-80 \%$, while severe COPD is between $30-50 \%$. The distribution is still appropriate to be studied as 2 groups.
The minimal clinically important difference (MCID) is the minimum difference which patients perceive as beneficial and which would mandate a change in patient management. ${ }^{3} \mathrm{MCID}$ can be used as a guide to evaluate whether the intervention can provides a minimum level of perceived benefit but the same MCID should be applied regardless of therapeutic modality. ${ }^{17,18}$

In this report, improvement of 6MWD reached MCID threshold. The difference of 6MWD between the first and the last measurement in overall subjects was 69.14 meters. $^{3}$ This result is still in the range of the previous study by Robert AW and Cynthia DB. They showed that the MCID for the 6MWD is 54-80 meters ${ }^{16,19}$ In Table 5, it shows that 6MWD difference in severe COPD group also achieved MCID threshold.

Continuing to focus on the large muscles of the inferior limb and shoulder ring muscles, Tobias Boeselt and colleagues conducted a study by giving exercise with the intensity starting from $35 \%$, and then increased up to $75 \%$ of the maximal muscle strength of exercise. This control study provided exercise with a frequency of 2 times per week for 90 minutes for three months. Subjects were mild to very severe COPD patients. There was a significant increase in distance in 6MWD in the exercise group compared to the control group. ${ }^{12}$

Tobias Boeselt and colleagues in their report recommended strength training 2-3 times a week and endurance training at moderate intensity 3-5 times a week. ${ }^{12}$ The American College od Sports Medicine also mentioned the possibility of musculoskeletal injury that can be reduced by heating, cooling, stretching, training progress and intensity. ${ }^{13}$ Hairmeyers in COPD is given to 
prevent injury and shortness of breath.

The frequency, intensity and duration of exercise are generally mentioned as 3 to 5 times a week. The intensity of $30 \%-39 \%$ of HR is moderate, $40 \%-59 \%$ of $\mathrm{HR}$ is vigorous, and $60 \%-89 \%$ is classified as maximal HR. The recommended time is 20 to 30 minutes per session, but in people who are very sedentary, less than 20 minutes is beneficial. ${ }^{9}$

In COPD disorders, the frequency and duration recommendations are the same as the intensity for aerobic exercise (50\% of maximum HR). ${ }^{9}$ Elizabeth et al on a systematic review analyzed about 20 studies of therapeutic exercise in COPD. Pulmonary Rehabilitation period is found between 4 weeks to 6 months. Most of the patients were intervened for 8 weeks. ${ }^{13}$

The subjects were evenly divided into two groups, but in the moderate group there were three female subjects. At the time of this research, the prevalence of men was indeed greater, but according to the GOLD 2020, the prevalence is equal in both genders. ${ }^{5}$ Increasing patterns of cigarette consumption in women, and studies which, while still controversial, say that women are more vulnerable to the effects of smoking, result in the same prevalence in both genders.

Age is included in the list of risk factors for COPD. Age increase, which means the structure of the lung, both in the airways and the parenchyma, changes, is related to the incidence of COPD. ${ }^{5}$ The age of the subjects in the two groups did not differ, i.e. more than 60 years, which is included in the criteria for the elderly. ${ }^{20,21}$
Although there was no difference in body weight and BMI between the two groups, the body height average was different. Body height affects walking distance. The taller the person, the longer the walking distance. The severe COPD group had higher body height average, probably because it consists of male subjects only, compared to the moderate group which had three female subjects. However, despite having higher body height average, the severe COPD group had lower 6MWD at the beginning of the study,,$^{23,25}$ most probably because of the severe COPD itself. ${ }^{22,23}$ Walking is a picture of daily activities. ${ }^{24}$ In this case the ability to walk is represented by $6 \mathrm{MWD}$, which is closely related to health status. As the intervention progressed, although the 6MWD increased in both groups, the difference was not statistically significant between two groups ( $p>0.05$ ).

Table 4 shows the effect of the intervention in each group. From the table we could see that the increase of 6MWD in the severe group was higher than the moderate group, although not statistically significant. Both groups, however, showed statistically significant improvement of 6MWD at the end of the $8^{\text {th }}$ week compared to the $6 \mathrm{MWD}$ before the exercise program.

\section{CONCLUSION}

Hairmyers exercise performed for eight weeks can be beneficial for patients with moderate and severe COPD. This study shows a significant improvement of 6MWD after 8 weeks of Hairmyers exercise training, which surpassed MCID threshold of 6MWD. 


\section{REFERENCES}

1. Schwellnus MP. Olympic Textbook of Medicine in Sport. Schwellnus MP, editor. Olympic Textbook of Medicine in Sport. Oxford, UK: Wiley-Blackwell; 2008.

2. Colby LA, Kisner C. Therapeutic exercise. 6th Ed. Foundations and techniques-F.A. Davis (2012). $6^{\text {th }}$ ed. Philadhelpia; 2012. 1-991 p.234-8

3. Rehabilitiation AA of C and P. Guidelines for Pulmonary Rehabilitation Programs. 2011.

4. Cielen N, Maes K, Gayan-Ramirez G. Musculoskeletal disorders in chronic obstructive pulmonary disease. Biomed Res Int. 2014;2014:1-17.

5. Global Initiative for Chronic Obstructive Lung Disease. Gold 2020. COPD J Chronic Obstr Pulm Dis. 2020;1-122.

6. Gea J, Pascual S, Casadevall C, Orozco-Levi $\mathrm{M}$, Barreiro E. Muscle dysfunction in chronic obstructive pulmonary disease: Update on causes and biological findings. J Thorac Dis. 2015;7:E418-38.

7. Muir JF, Pierson DJ. Pulmonary rehabilitation in chronic respiratory insufficiency: Introduction. Thorax. 1994;49:270-8.

8. Clark CJ, Cochrane L,Mackay E. Low intensity peripheral muscle conditioning improves exercise tolerance and breathlessness in COPD. Eur Respir J. 1996;9:2590-6.

9. Riebe D, Ehrman J K, Liguori G MM. 508 ACSM's Guidelines for Exercise-10 $0^{\text {th }}$ edition. pdf. tenth edit. Wolters Kluwer; 2018.

10. Morales-Blanhir JE, Vidal CDP, de Jesús Rosas Romero M, Castro MMG, Villegas AL, Zamboni M. Six-minute walk test: A valuable tool for assessing pulmonary impairment. J Bras Pneumol. 2011;37:110-7.
11. Liu WY, Meijer K, Delbressine JM, Willems PJ, Franssen FME, Wouters EFM, Spruit MA. Reproducibility and validity of the 6-minute walk test using the gait real-time analysis interactive lab in patients with COPD and healthy elderly. PLoS One. 2016;11:1-11.

12. Boeselt T, Nell C, Lütteken L, Kehr K, Koepke J, Apelt S, Veith M, BEutel B, Spielmanns M, Greulich T, Vogelmiere DF, Kenn K, Janciauskiene S, Alter P, Koczulla AR. Benefits of High-Intensity Exercise Training to Patients with Chronic Obstructive Pulmonary Disease: A Controlled Study. Respiration. 2017;93:301-10.

13. Moore E, Palmer T, Newson R, Majeed A, Quint JK, Soljak MA. Pulmonary Rehabilitation as a Mechanism to Reduce Hospitalizations for Acute Exacerbations of COPD: A Systematic Review and MetaAnalysis. Chest. 2016;150:837-59.

14. Ryrsø CK, Godtfredsen NS, Kofod LM, Lavesen M, Mogensen L, Tobberup R, Vestergaard IF, Callesen HE, Tendal B, Lange P, Lepsen UW. Lower mortality after early supervised pulmonary rehabilitation following COPD-exacerbations: a systematic review and meta-analysis. BMC Pulm Med. 2018 Sep 15;18(1):154.

15. Hoffman M, Chaves G, Ribeiro-Samora GA, Britto RR, Parreira VF. Effects of pulmonary rehabilitation in lung transplant candidates: A systematic review. BMJ Open. 2017;7:1-10.

16. Wise RA, Brown CD. Minimal clinically important differences in the six-minute walk test and the incremental shuttle walking test. COPD J Chronic Obstr Pulm Dis. 2005;2:125-9.

17. Donohue JF. Minimal clinically important differences in COPD lung function. COPD J Chronic Obstr Pulm Dis. 2005;2:111-24. 
18. Jones PW, Beeh KM, Chapman KR, Decramer M, Mahler DA, Wedzicha JA. Minimal clinically important differences in pharmacological trials. Am J Respir Crit Care Med. 2014;189:250-5.

19. Issues S, Test MW, Equipment R, Preparation P. American Thoracic Society ATS Statement : Guidelines for the Six-Minute Walk Test. 2002;166:111-7.

20. Incalzi RA, Scarlata S, Pennazza G, Santonico $\mathrm{M}$, Pedone C. Chronic obstructive pulmonary disease in the elderly. Eur J Intern Med. 2014;25:320-8.

21. Divo MJ, Celli BR, Poblador-Plou B, Calderón-Larrañaga A, de-Torres JP, GimenoFeliu LA, Berto J, Zulueta JJ, Casanoca C, Pintoplata VM, Lopez CC, Polverino F, Pirez JC, Torres AP, Marin JM. Chronic Obstructive Pulmonary Disease (COPD) as a disease of early aging: Evidence from the EpiChron Cohort. PLoS One. 2018;13:1-16.
22. Burkhardt R, Pankow W. The Diagnosis of Chronic Obstructive Pulmonary Disease. Dtsch Arztebl Int. 2014;111:834-46.

23. Camarri B, Eastwood PR, Cecins NM, Thompson PJ, Jenkins S. Six minute walk distance in healthy subjects aged 55-75 years. Respir Med. 2006;100:658-65.

24. Valenti G, Bonomi AG, Westerterp KR. Walking as a Contributor to Physical Activity in Healthy Older Adults: 2 Week Longitudinal Study Using Accelerometry and the Doubly Labeled Water Method. JMIR mHealth uHealth. 2016;4:e56.

25. Casanova C, Celli BR, Barria P, Casas A, Cote C, De Torres JP, Jardim J, Lopez MV, Marin JM, Montes de oca M, Plata VP, Aguirrejaime A. The 6-min walk distance in healthy subjects: Reference standards from seven countries. Eur Respir J. 2011;37:150-6. 